\title{
БИОЛОГИЯ
}

УДК 591.69-82:598.243 (571.54)

DOI 10.18101/2542-0623-2019-3-7-32

\section{ЭКОЛОГО-ФАУНИСТИЧЕСКИЙ АНАЛИЗ ГЕЛЬМИНТОВ ВОДНО-БОЛОТНЫХ ПТИЦ БАЙКАЛЬСКОЙ СИБИРИ: 2. РЖАНКОВЫЕ CHARADRII}

\section{Ц. 3. Доржиев, Е. Н. Бадмаева, Ж. Н. Дугаров}

(C) Доржиев Цыдыпжап Заятуевич

доктор биологических наук, профессор,

Бурятский государственный университет имени Доржи Банзарова

Россия, 670000, г. Улан-Удэ, ул. Смолина, 24а

E-mail: tsydypdor@mail.ru

\section{(C) Бадмаева Евгения Николаевна}

кандидат биологических наук, доцент,

Бурятский государственный университет имени Доржи Банзарова Россия, 670000, г. Улан-Удэ, ул. Смолина, 24а

E-mail: calidris03@gmail.com

\section{(C) Дугаров Жаргал Нимаевич}

кандидат биологических наук, старший научный сотрудник, Лаборатория паразитологии и экологии гидробионтов, Институт общей и экспериментальной биологии СО РАН Россия, 670047, г. Улан-Удэ, ул. Сахьяновой, 6 E-mail: zhar-dug@biol.bscnet.ru

Проведен эколого-фаунистический анализ гельминтов подотряда ржанковых птиц Байкальской Сибири. Основной материал собран на оз. Байкал. Установлено систематическое разнообразие гельминтофауны, которая насчитывает 88 видов из 4 классов и 17 семейств. В видовом отношении преобладали цестоды (40,9\% видового богатства), трематоды составляли чуть более одной трети $(34,1)$, нематоды - одна пятая часть $(23,7)$, скребни - единицы $(1,1)$.

Соотношение представителей разных классов паразитов в подсемействах ржанковых птиц заметно отличалось. У одних (ржанков, бекасовых и песочников) преобладали цестоды, у других (чибисовых, камнешарок, веретенниковых, улитов и плавунчиковых) - трематоды. Наибольшее видовое богатство паразитов отмечено у куликаворобья, фифи, мородунки.

Широкий круг хозяев среди ржанковых птиц имели цестоды Aploparaksis sachalinensis, Anomotaenia tringae, Aploparaksis crassirostris, Anomotaenia citrus, трематоды Plagiorchis nanus, Cyclocoelum mutabile, Leucochloridium actitis, Echinoparyphium politum, Plagiorchis vitellatus, нематоды Tetrameres dubia Porrocaecum semiteres. Выявлено немало специфических для ржанковых птиц гельминтов (род Anomotaenia - A. citrus, A. globulus, A. tringae u дp., Pseudanomotaenia paramicrorhyncha, Trichocephaloides megalocephala, Aploparaksis sachalinensis и др.). 
Гельминтофауна разных подсемейств ржанковых птиц отличалась относительно небольшим сходством, что объясняется различиями в питании, кормодобывательном поведении и местах кормления разных видов.

Ключевые слова: гельминты; паразиты птиц; ржанковые птицы; оз. Байкал; Байкальская Сибирь; гельминтофауна.

\section{Для цитирования}

Доржиев Ц. 3., Бадмаева Е. Н., Дугаров Ж. Н. Эколого-фаунистический анализ гельминтов водно-болотных птиц Байкальской Сибири: 2. Ржанковые Charadrii // Природа Внутренней Азии. Nature of Inner Asia. 2019. № 3(12). С. 7-32.

DOI: $10.18101 / 2542-0623-2019-3-7-32$

\section{Введение}

Данная статья является продолжением публикаций о гельминтах разных систематических групп водно-болотных птиц Байкальской Сибири. Она посвящена паразитам подотряда ржанковых Charadrii. В предыдущей работе мы рассматривали гельминтов утиных птиц (Доржиев, Бадмаева, Дугаров, 2019). В этом плане ржанковые птицы Байкальской Сибири изучены слабо (Тупицын, Тимошенко, 1996; Некрасов, 2000).

Цель настоящей работы - выявление эколого-фаунистических особенностей гельминтов подотряда ржанковых птиц Charadrii в Байкальской Сибири.

\section{Материал и методика}

Работа написана на основании анализа литературных сведений и неопубликованных данных А. В. Некрасова и его коллег о гельминтах ржанковых птиц, собранных ими в 1971-2003 гг. в разных районах Байкальской Сибири - оз. Байкал (дельты рек Верхняя Ангара и Кичера, Северобайкальский сор, Чивыркуйский и Баргузинский заливы, оз. Арангатуй, дельта р. Селенги, Истоминский сор, Малое море) и Юго-Западное Забайкалье (оз. Гусиное, Цайдамские озера и Белые озера в долине р. Боргой). Вскрытия птиц были проведены по методике полного и неполного гельминтологического вскрытия по К. И. Скрябину. Видовая принадлежность цестод определена по Л. П. Спасской (1966), нематод и трематод по А. А. Шевцову, Л. Н. Заскинду (1960).

В Байкальской Сибири зарегистрировано 58 видов подотряда ржанковых птиц, из них 21 - гнездящиеся, 22 - пролетные и 15 - залетные (Доржиев, 2011; Доржиев, Бадмаева, 2016). В данной работе представлен 31 вид, относящийся к двум семействам (ржанковые Charadriidae и бекасовые Scolopacidae) и 8 подсемействам. Исследованные птицы - это 16 перелетных гнездящихся, 14 - пролетных и 1 - залетного вида. Из семейства ржанковых изучено 5 видов, принадлежащих к 3 подсемействам, из семейства бекасовых - 26 видов из 5 подсемейств (табл. 1). Дана краткая характеристика экологии питания хозяев, поскольку, как известно, рацион определенным образом влияет на видовое разнообразие гельминтов.

Всего вскрыта 261 особь ржанковых птиц. Объем материала в целом по видам небольшой, лишь по некоторым из них (чибис, большой веретенник, поручейник, большой улит, фифи, кулик-воробей) число обследованных птиц превышает 10 и более особей (табл. 1). 
Ц. З. Доржиев, Е. Н. Бадмаева, Ж. Н. Дугаров. Эколого-фаунистический анализ гельминтов водноболотных птиц Байкальской Сибири: 2. Ржанковые Charadrii

Таблий 1

Число исследованных видов подотряда ржанковых птиц и характер их пребывания в Байкальской Сибири

\begin{tabular}{|c|c|c|c|}
\hline № & Названия птиц & $\begin{array}{c}\text { Изучено } \\
\text { особей }\end{array}$ & $\begin{array}{c}\text { Характер пребы- } \\
\text { вания } \\
\end{array}$ \\
\hline & \multicolumn{3}{|c|}{ Семейство Ржанковые Charadrii } \\
\hline & \multicolumn{3}{|c|}{ Подсемейство Чибисовые Vanellinae } \\
\hline 1 & Чибис Vanellus vanellus & 50 & гн \\
\hline & \multicolumn{3}{|c|}{ Подсемейство Ржанки Charadriinae } \\
\hline 2 & Бурокрылая ржанка Pluvialis fulva & 1 & пр \\
\hline 3 & Галстучник Charadrius hiaticula & 4 & пр \\
\hline 4 & Малый зуек Charadrius dubius & 3 & Гн \\
\hline & \multicolumn{3}{|c|}{ Подсемейство Камнешарки Arenariinae } \\
\hline 5 & Камнешарка Arenaria interpres & 1 & пр \\
\hline & \multicolumn{3}{|c|}{\begin{tabular}{|l|} 
Семейство Бекасовые Scolopacidae \\
\end{tabular}} \\
\hline & \multicolumn{3}{|c|}{ Подсемейство Бекасовые Scolopacinae } \\
\hline 6 & Вальдшнеп Scolopax rusticola & 1 & гн \\
\hline 7 & Азиатский бекас Gallinago stenura & 5 & $\Gamma \mathrm{H}$ \\
\hline 8 & Лесной дупель Gallinago megala & 1 & $\Gamma \mathrm{H}$ \\
\hline 9 & Бекас Gallinago gallinago & 8 & гн \\
\hline & \multicolumn{3}{|c|}{ Подсемейство Веретенниковые Numeniinae } \\
\hline 10 & $\begin{array}{l}\text { Азиатский бекасовидный веретенник } \\
\text { Limnodromus semipalmatus }\end{array}$ & 1 & $\Gamma \mathrm{H}$ \\
\hline 11 & Большой веретенник Limosa limosa & 28 & ГН \\
\hline 12 & Малый веретенник Limosa lapponica & 1 & зал \\
\hline 13 & Кроншнеп-малютка Numenius minutus & 3 & пр \\
\hline 14 & Средний кроншнеп Numenius phaeopus & 1 & пр \\
\hline 15 & Большой кроншнеп Numenius arquata & 3 & Гн \\
\hline & \multicolumn{3}{|c|}{\begin{tabular}{|l|} 
Подсемейство Улиты Tringinae \\
\end{tabular}} \\
\hline 16 & Щеголь Tringa erythropus & 21 & пр \\
\hline 17 & Поручейник Tringa stagnatilis & 44 & ГН \\
\hline 18 & Большой улит Tringa nebularia & 14 & Гн \\
\hline 19 & Черныш Tringa ochropus & 3 & Гн \\
\hline 20 & Фифи Tringa glareola & 32 & Гн \\
\hline 21 & Сибирский пепельный улит Heteroscelus brevipes & 3 & пр \\
\hline 22 & Перевозчик Actitis hypoleucos & 6 & ГН \\
\hline \multirow[t]{2}{*}{23} & Мородунка Xenus cinereus & 2 & пр \\
\hline & \multicolumn{3}{|c|}{ Подсемейство Плавунчиковые Phalaropodinae } \\
\hline 24 & Круглоносый плавунчик Phalaropus lobatus & 1 & пр \\
\hline & \multicolumn{3}{|c|}{ Подсемейство Песочники Calidridinae } \\
\hline 25 & Кулик-воробей Calidris minuta & 12 & пр \\
\hline 26 & Длиннопалый песочник Calidris subminuta & 2 & ГН \\
\hline 27 & Белохвостый песочник Calidris temminckii & 1 & пр \\
\hline 28 & Краснозобик Calidris ferruginea & 6 & пр \\
\hline 29 & Чернозобик Calidris alpina & 1 & пр \\
\hline 30 & Острохвостый песочник Calidris acuminata & 1 & пр \\
\hline 31 & Турухтан Phylomachus pugnax & 2 & ГН \\
\hline
\end{tabular}




\section{Результаты и обсуждение}

Рассмотрим более подробно зараженность гельминтами приведенных птиц по таксономическим группам.

Семейство ржанковые птицы. В Байкальской Сибири данная группа представлена 13 гнездящимися, пролетными и залетными видами. Из них исследовано на зараженность гельминтами 5 видов: чибис и малый зуек перелетные гнездящиеся, остальные 3 вида - бурокрылая ржанка, галстучник и камнешарка - пролетные.

Относительно полную картину зараженности гельминтами получили по чибису (вскрыто 50 особей), по остальным видам объем выборки небольшой. В табл. 2 показано разнообразие гельминтов 3 подсемейств данного семейства - чибисов, ржанок и камнешарок.

Подсемейство чибисов в регионе представлено только одним видом - чибисом. Рацион этих птиц очень разнообразный, но преимущественно - насекомые. Анализ питания, проведенный в летнее время в дельте р. Селенги, показал преобладание насекомых (97\%), другие виды корма встречались заметно меньше: моллюски $39 \%$, семена растений - 30\%, гаммариды - $15 \%$, растительные остатки - $12 \%$ и пауки - $12 \%$ (Фефелов и др., 2001). Встречаемость последних весной бывает выше. В желудках двух птиц, добытых нами в начале июня на лугу вблизи оз. Камышовое (Гусиноозерская котловина), обнаружены остатки взрослых жужелиц, немного саранчовых, гусениц насекомых, пауков (вместе около 80\% содержимого желудка), молодые побеги травянистых растений (8-10\%), семена (5-8\%), несколько экземпляров моллюсков и гаммарид. В другом случае в желудке одного чибиса, добытого в июне в том же месте, семена и побеги растений составляли почти половину содержимого желудка, различные виды беспозвоночных остальную часть.

Выявлено у чибисов 25 видов гельминтов, в том числе цестод - 6 , трематод 15 и нематод - 4 вида (табл. 2). Лентец Anomotaenia stentorea был зарегистрирован только у чибиса, у других исследованных видов птиц Байкальской Сибири его не встречали. В других регионах он отмечается у разных видов куликов (Валуев, 2006). Echinocotyle magnisaccis зарегистрирована в регионе, помимо чибиса, у большого веретенника. Цестода Wardium fusa отсутствовала у других ржанковых, ею были заражены только некоторые виды чаек. Трематода Echinostoma paraulum и нематода Tetrameres fissispina среди ржанкообразных птиц не попадались, они обнаружены в поганках и утках, также как и в других регионах (Пенкина и др., 2017). В то же время такие обычные для ржанковых птиц гельминты, как Anomotaenia citrus, Aploparaksis sachalinensis, Cyclocoelum mutabile и другие, не обнаружены у чибисов. Количество зараженных чибисов составило 88\%. 
Ц. З. Доржиев, Е. Н. Бадмаева, Ж. Н. Дугаров. Эколого-фаунистический анализ гельминтов водноболотных птиц Байкальской Сибири: 2. Ржанковые Charadrii

Гельминты семейства ржанковых птиц

Таблица 2 в Байкальской Сибири

\begin{tabular}{|c|c|c|c|c|c|}
\hline \multirow[b]{2}{*}{ Гельминты } & \multirow[b]{2}{*}{ 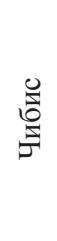 } & \multicolumn{4}{|c|}{ Ржанки } \\
\hline & & 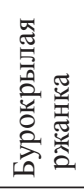 & 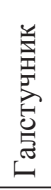 & 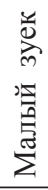 & 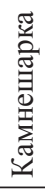 \\
\hline \multicolumn{6}{|l|}{ Цестоды Cestoda } \\
\hline Pseudanomotaenia paramicrorhyncha (Bloch, 1779) & & & & + & \\
\hline Anomotaenia clavigera (Krabbe, 1869) & & & & + & \\
\hline Anomotaenia microphallos (Krabbe, 1869) & + & + & & & \\
\hline Anomotaenia microrhyncha (Krabbe, 1869) & + & & & & \\
\hline Anomotaenia globulus (Wedl, 1855) & & + & & & \\
\hline Anamotaenia mollis (Volz, 1900) & & & + & & \\
\hline Anomotaenia citrus (Krabbe, 1869) & & & & + & \\
\hline Anomotaenia stentorea (Fröelich, 1802) & + & & & & \\
\hline Anomotaenia tringae (Burt, 1940) & & & + & + & \\
\hline Kowalewskiella cingulifera (Krabbe, 1869) & & & & + & \\
\hline Nototaenia brevis (Linstow, 1884) & & + & & & \\
\hline Panuwa guiarti (Tseng, 1932) & & & & + & \\
\hline Polycercus paradoxa (Rudolphi, 1802) & & & & + & \\
\hline Aploparaksis crassirostris (Krabbe, 1869) & & & & + & \\
\hline Aploparaksis sachalinensis (Krotov, 1952) & & & & + & \\
\hline Aploparaksis sanjuanensis (Tubangui et Masilungan, 1937) & & & & + & \\
\hline Echinocotyle magnisaccis (Meggitt, 1927) & + & & & & \\
\hline Echinocotyle uralensis (Clerc, 1902) & + & & & & \\
\hline Liga brevis (Linstow, 1884) & & + & & & \\
\hline Wardium fusa (Krabbe, 1869) & + & & & & \\
\hline \multicolumn{6}{|c|}{ Трематоды Trematoda } \\
\hline Cyclocoelum microstomum (Creplin, 1829) & + & & & & \\
\hline Cyclocoelum halli (Harrah, 1922) & + & & & & \\
\hline Cyclocoelum tringae (Stossich, 1902) & + & & & & \\
\hline Cyclocoelum mutabile (Zeder, 1800) & + & & & & + \\
\hline Uvitellina adelpha (Johnston, 1916) & + & & + & + & \\
\hline Uvitellina vanelli (Rudolphi, 1819) & + & & & & \\
\hline Cotylurus cornutus (Rudolphi, 1808) & + & & & & \\
\hline Echinoparyphium recurvatum (Linstow, 1873) & + & & & & \\
\hline
\end{tabular}




\begin{tabular}{|c|c|c|c|c|c|}
\hline \multirow[b]{2}{*}{ Гельминты } & \multirow[b]{2}{*}{ 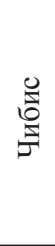 } & \multicolumn{4}{|c|}{ Ржанки } \\
\hline & & 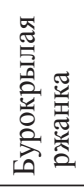 & 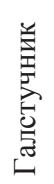 & 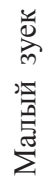 & 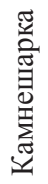 \\
\hline Echinoparyphium clerci (Skrjabin, 1915) & + & & & & \\
\hline Echinoparyphium nordiana (Baschkirova, 1941) & + & & & & \\
\hline Echinostoma paraulum (Dietz, 1909) & + & & & & \\
\hline Leucochloridium actitis (McIntosh, 1932) & + & & & + & \\
\hline Longicollia echinata (Bychowskaja-Pawlowskaja, 1953) & + & & & & \\
\hline Notocotylus linearis (Rudolphi, 1819) & + & & & & \\
\hline Plagiorchis nanus (Rudolphi, 1802) & & & + & + & \\
\hline \multicolumn{6}{|l|}{ Plagiorchis vitellatus (Linstow, 1875) } \\
\hline Plagiorchis nyrocae (Ryjikov et Timofeeva, 1962) & & & + & & \\
\hline Prosthogonimus ovatus (Rudolphi, 1803) & + & & & & \\
\hline Tanaisia fedtschenkoi (Skrjabin, 1924) & & & + & + & \\
\hline Parorchis gedoelsti (Skrjabin, 1924) & & & & & + \\
\hline \multicolumn{6}{|c|}{ Нематоды Nematoda } \\
\hline Strongyloides turkmenica (Kurtieva, 1953) & & & & & + \\
\hline Tetrameres dubia (Travassos, 1917) & & & + & & \\
\hline Tetrameres fissispina (Diesing, 1861) & + & & & & \\
\hline Thominx limicolae (Mamaev, 1959) & & + & & & \\
\hline Eucoleus trilobus (Linstow, 1875) & & & + & + & \\
\hline Amidostomum henryi Skrjabin, 1915 & + & & & & \\
\hline Porrocaecum semiteres (Zeder, 1800) & + & + & + & & \\
\hline Porrocaecum ensicaudatum (Zeder, 1800) & + & & & & \\
\hline
\end{tabular}

В подсемействе ржсанки было исследовано только три вида - бурокрылая ржанка, галстучник, малый зуек. Первые два вида отмечаются в регионе в период миграций, а малый зуек является гнездящейся птицей. Питание их в регионе не изучено. Обычно бурокрылые ржанки во время пролета кормятся в открытых местах, чаще в степи и на лугу. На осеннем пролете в районе Малого моря на Байкале они питались в основном наземными формами насекомых, из которых наиболее существенное значение имели жуки-долгоносики, саранчовые и жужелицы (30,3; 22,7 и 13,6\% по объему соответственно) (Пыжьянов, Соколовская, Дубешко, 2013). Гастучники держатся по берегам водоемов. Малые зуйки собирают корм на песчаных и галечниковых берегах рек и озер, редко на песчаных почвах в степи. Рацион всех видов преимущественно состоит из наземных насекомых. По местам кормления, как видно, представители ржанок хорошо дифференцированы. Добыто и вскрыто очень мало особей, поэтому материала для выявления реальной картины видового разнообразия гельминтов явно не хватает. 
Ц. З. Доржиев, Е. Н. Бадмаева, Ж. Н. Дугаров. Эколого-фаунистический анализ гельминтов водноболотных птиц Байкальской Сибири: 2. Ржанковые Charadrii

У единственно добытой бурокрылой ржанки обнаружено 6 видов гельминтов: цестод - 4, нематод - 2 вида. Из них лентецы Nototaenia brevis, Liga brevis и круглый червь Thominx limicolae — только у этого вида, у других ржанок региона не зарегистрированы. В Монголии у этой ржанки зарегистрирован круглый червь Oxyspirura lobipluvia (Danzan, 1964).

У 4 вскрытых галстучников были заражены гельминтами три птицы (75\%), у которых выявили 9 видов паразитов: цестод - 2, трематод - 4, нематод - 3 . Виды были обычными для многих других ржанковых.

Maльlх зуйков обследовано всего три особи, только одна из них была зараженной $(33,3 \%)$, причем довольно большим числом видов гельминтов. Из нее извлечено 15 видов, в том числе цестод - 10 , трематод -4 и нематод -1 . Только у этого вида среди ржанкообразных региона выявлен лентец Panuwa guiarti. Он также не был обнаружен среди других водно-болотных птиц Байкальской Сибири. Остальные виды гельминтов малого зуйка отмечены у отдельных видов ржанковых в регионе.

Подсемейство камнешарок представлено в Байкальской Сибири одним видом - камнешаркой, которая отмечается на пролете. Исследована единственная особь, у которой обнаружили 2 вида трематод, 1 - нематод. Все они найдены у других ржанкообразных региона.

Семейство бекасовые птицы. Данное семейство среди ржанкообразных птиц Байкальской Сибири самое богатое, отмечен 41 вид: гнездящихся - 16, пролетных - 17 и залетных -8 .

Подсемейство бекасов в исследуемом регионе представлено 6 видами, из них обследовано 5 гнездящихся видов (табл. 1). Вальдшнеп, как известно из других районов ареала, преимущественно питается дождевыми червями и личинками насекомых, остальные исследованные нами виды - азиатский бекас, лесной дупель и обыкновенный бекас - водными насекомыми и их личинками, реже моллюсками. В табл. 3 показана зараженность гельминтами бекасовых птиц Байкальской Сибири.

У единственной особи вальдинепа обнаружено 2 вида цестод, 4 - нематод. Среди них выявлен лентец Kowalewskiella cingulifera, известный как паразит лесных куриных птиц. Видимо, вальдшнеп, обитая в лесных биотопах, имеет опосредованный контакт с некоторыми из них. Этот вид цестоды, как ни странно, обнаружен у куликов - длиннопалого песочника. Остальные виды гельминтов вальдшнепа обычны для некоторых ржанковых.

Из 5 азиатских бекасов 3 были заражены цестодами - 10 видов, трематодами - 7 и нематодами - 4. Из них лентецы Anomotaenia ancora и Echinocotyle nitida встречены только у этого вида, у других птиц региона они не обнаружены.

У единственного вскрытого лесного дупеля выявлен один вид трематоды Echinostoma stantschinskii, которая паразитировала только у него и обыкновенного бекаса. У других видов птиц региона она не отмечена.

Обыкновенный бекас представлен 8 особями, из них 5 были заражены гельминтами. Всего выявлено 15 видов гельминтов, в том числе цестод -6, трематод 6 и нематод - 3. Большинство паразитов были обычными для других видов ржан- 
ковых Байкальской Сибири, только Aploparaksis spinosus обнаружена у обыкновенного бекаса, у остальных исследованных птиц в регионе она не выявлена, хотя этот вид встречается в других районах ареала у разных видов ржанковых птиц. Другой вид из рода Aploparaksis maтaevi оказался кроме бекаса у фифи.

Таблица 3

Гельминты подсемейств бекасовых и веретенниковых птиц в Байкальской Сибири

\begin{tabular}{|c|c|c|c|c|c|c|c|c|c|c|}
\hline \multirow[b]{2}{*}{ Гельминты } & \multicolumn{4}{|c|}{ Бекасовые } & \multicolumn{6}{|c|}{ Веретенниковые } \\
\hline & 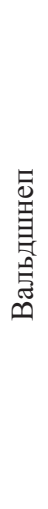 & 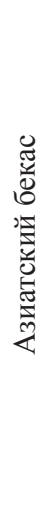 & 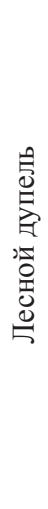 & 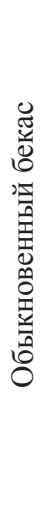 & 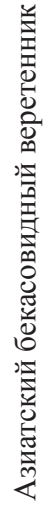 & 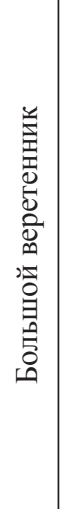 & 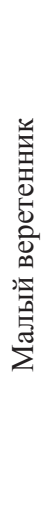 & 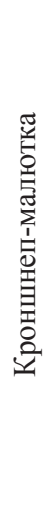 & 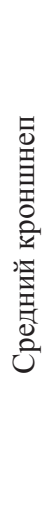 & 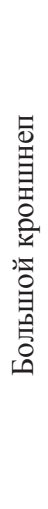 \\
\hline \multicolumn{11}{|c|}{ Цестоды Cestoda } \\
\hline Pseudanomotaenia paramicrorhyncha (Bloch, 1779) & & + & & & & & & & & \\
\hline Dilepis undula (Schrank, 1788) & & & & & & & & + & & \\
\hline Anomotaenia nymphaea (Schrank, 1790) & & & & & & & & + & + & + \\
\hline Anomotaenia ancora (Mamajew, 1959) & & + & & & & & & & & \\
\hline Anomotaenia citrus (Krabbe, 1869) & + & + & & & & & & & & \\
\hline Anomotaenia tringae (Burt, 1940) & & + & & & & & & & & \\
\hline Kowalewskiella cingulifera (Krabbe, 1869) & + & & & & & & & & & \\
\hline Polycercus paradoxa (Rudolphi, 1802) & & + & & & & & & & & \\
\hline Aploparaksis crassirostris (Krabbe, 1869) & & + & & + & & & & + & & \\
\hline Aploparaksis mamaevi (Bondarenko, 1966) & & & & + & & & & & & \\
\hline $\begin{array}{l}\text { Aploparaksis sanjuanensis (Tubangui et } \\
\text { Masilungan, 1937) }\end{array}$ & & + & & + & & & & & & \\
\hline Aploparaksis secessivus (Gubanov et Mamaev, 1959) & & & & + & & & & & & \\
\hline Aploparaksis spinosus (Bondarenko, 1966) & & & & + & & & & & & \\
\hline Aploparaksis filum (Goeze, 1782) & & + & & & & & & & & \\
\hline Echinocotyle magnisaccis (Meggitt, 1927) & & & & & & + & & & & \\
\hline Echinocotyle nitida (Clerc, 1902, 1903) & & + & & & & & + & & & \\
\hline Nadejdolepis nitida (Krabbe, 1869) & & + & & + & & & + & & & \\
\hline
\end{tabular}


Ц. З. Доржиев, Е. Н. Бадмаева, Ж. Н. Дугаров. Эколого-фаунистический анализ гельминтов водноболотных птиц Байкальской Сибири: 2. Ржанковые Charadrii

\begin{tabular}{|c|c|c|c|c|c|c|c|c|c|c|}
\hline \multirow[b]{2}{*}{ Гельминты } & \multicolumn{4}{|c|}{ Бекасовые } & \multicolumn{6}{|c|}{ Веретенниковые } \\
\hline & 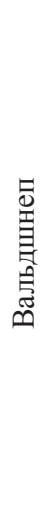 & 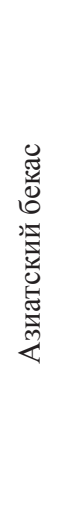 & 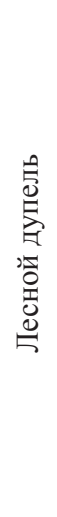 & 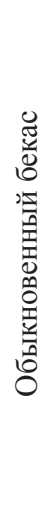 & 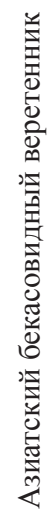 & 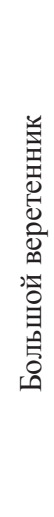 & 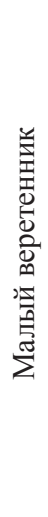 & 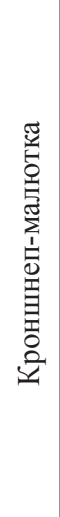 & 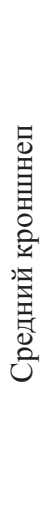 & 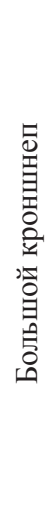 \\
\hline Passerilepis crenata (Goeze, 1782) & & & & & & & + & & & \\
\hline \multicolumn{11}{|c|}{ Трематоды Trematoda } \\
\hline Cyclocoelum tringae (Stossich, 1902) & & & & & & + & & & & \\
\hline Cyclocoelum mutabile (Zeder, 1800) & & + & & + & & + & & & & \\
\hline Uvitellina vanelli (Rudolphi, 1819) & & & & & & + & & & & \\
\hline Echinoparyphium politum (Skrjabin, 1915) & & + & & + & & & & & & \\
\hline Echinostoma paraulum (Dietz, 1909) & & & & & & + & & & & \\
\hline Echinostoma revolutum (Fröhlich, 1802) & & & & & & & & + & & \\
\hline Echinostoma stantschinskii (Semenov, 1927) & & + & + & & & & & & & \\
\hline Leucochloridium actitis (McIntosh, 1932) & & + & & & & & & + & & + \\
\hline $\begin{array}{l}\text { Longicollia echinata (Bychowskaja-Pawlowskaja, } \\
\text { 1953) }\end{array}$ & & + & & + & & + & & & & \\
\hline Plagiorchis nanus (Rudolphi, 1802) & & + & & + & & & + & + & & + \\
\hline Plagiorchis uhlwormi (Massino, 1927) & & & & & & + & & + & & + \\
\hline Prosthogonimus cuneatus (Rudolphi, 1809) & & & & + & & & & & & \\
\hline Tanaisia fedtschenkoi (Skrjabin, 1924) & & + & & + & & & & & & \\
\hline Schistogonimus rarus (Braun, 1901) & & & & & & & & & & + \\
\hline \multicolumn{11}{|c|}{ Нематоды Nematoda } \\
\hline Syngamus gibbocephalus (Ryjikov, 1949) & + & + & & + & & & & & & \\
\hline Tetrameres dubia (Travassos, 1917) & + & + & & & & & & & & \\
\hline Tetrameres numenii (Mamaev, 1959) & & & & & & & & & & + \\
\hline Tetrameres limicollis (Sercova, 1948) & + & + & & + & & & & & & \\
\hline Cosmocephalus obvelatus (Creplin, 1825) & & & & & & + & & & & \\
\hline Porrocaecum semiteres (Zeder, 1800) & + & + & & + & & & & & & \\
\hline Cosmocephalus obvelatus (Creplin, 1825) & & & & & + & & & & & \\
\hline \multicolumn{11}{|c|}{ Акантоцефала Acanthacephala } \\
\hline Polymorphus gen. sp. & & & & & & & & & & + \\
\hline
\end{tabular}


Подсемейство веретенниковых в Байкальской Сибири насчитывает 8 видов, из них обследовано 6, среди них 3 - гнездящиеся и 3 - пролетные. Особенности питания веретенниковых птиц в регионе изучены недостаточно. Известно, что эти птицы обычно поедают животный корм (преимущественно беспозвоночных), а также семена и стебли растений, но у разных видов рацион хорошо отличается, поскольку кормовые стации и способы добывания корма видоспецифичны. Азиатский бекасовидный веретенник и большой веретенник обычно добывают пищу на сыром мягком грунте или в иле в мелководье. Большую часть рациона большого веретенника в дельте р. Селенги составляют различные наземные и водные насекомые, более $20 \%$ объема корма - семена растений и несколько меньше (16\%) — моллюски (Фефелов и др., 2011). Средние кроншнепы во время пролета часто кормятся на лугу и в степи. В желудке одной добытой нами 23 мая птицы в степи - окр. с. Гурульба (недалеко от г. Улан-Удэ), обнаружили жужелиц и других жуков, остатки паука, небольшое количество семян растений. Большой кроншнеп преимущественно питается на лугу, где, видимо, ловит различных беспозвоночных. В желудках трех птиц, добытых осенью на Малом море, обнаружены в основном саранчовые ( $45 \%$ по объему), жужелицы (35\%), листоеды (около 15\%) и другие жесткокрылые (5\%) [Пыжьянов, Соколовская, Дубешко, 2013]. В табл. 3 представлена зараженность гельминтами веретенниковых птиц Байкальской Сибири.

Азиатский бекасовидный веретенник вскрыт в единственном экземпляре. Обнаружен один вид нематоды Cosmocephalus obvelatus, которая у других видов веретенников отсутствовала, но паразитировала в регионе у щеголя, большого улита и фифи.

Больщой веретенник среди веретенниковых представлен в сборе большим количеством. Из 28 исследованных особей 17 (60,7\%) были заражены гельминтами. Обнаружено всего 8 видов паразитов, из них 1 вид - цестоды и 7 - трематоды. Лентец Echinocotyle magnisaccis зарегистрирован в Байкальской Сибири, как отмечали ранее, только у данного вида и чибиса. Трематода Cyclocoelum tringae в регионе обнаружена только у большого веретенника, она может паразитировать и у других видов куликов [Кириллов, Кириллова, 2013]. Два вида сосальщиков (Uvitellina vanelli, Echinostoma paraulum) не выявлены у прочих веретенниковых, но первая паразитировала у чибиса и большого улита, а вторая была обычной у многих водоплавающих птиц. Из нематод Cosmocephalus obvelatus помимо данного вида была зарегистрирована у некоторых видов улитов. Из скребней обнаружен один вид, которого не удалось определить, в соседнем регионе на Хубсугуле из данного рода обнаружена Poymorphus таgnus (Danzan, 1964; Ganzorig, Danzan, 1990). Остальные виды гельминтов широко были распространены у других веретенниковых.

Мальий веретенник в сборе представлен единственным экземпляром. У него обнаружено 4 вида гельминтов, в том числе 3 - цестоды и 1 - трематода. Все паразиты были отмечены, за исключением Passerilepis crenata (выявлена еще у перевозчика), у других веретенниковых. 
Ц. З. Доржиев, Е. Н. Бадмаева, Ж. Н. Дугаров. Эколого-фаунистический анализ гельминтов водноболотных птиц Байкальской Сибири: 2. Ржанковые Charadrii

Кроншнеп-малютка обследована в количестве трех особей. Все они были заражены, зарегистрировано 7 видов гельминтов: 3 - цестоды, 4 - трематоды. Цестода Dilepis undula отмечена среди веретенниковых только у этого вида и обнаружена в регионе также у тетерева. Обычно заражение этим гельминтом происходит через дождевых червей, поэтому он встречается у разных систематических групп птиц, поедающих их [Дзармотова, Плиева, 2012]. В личиночной форме Dilepis undula паразитирует у насекомоядных млекопитающих (Меркушева, Бобкова, 1981; Юшков, 1995; Аниканова и др., 2001). Среди сосальщиков Echinostoma revolutum обнаружен у кроншнепа-малютки, у других веретенниковых не было, хотя паразитировал в Байкальской Сибири у многих видов чаек, крачек, поганок и уток.

Средний кроншнеп изучен в единственном числе, у него выявлен один вид цестоды Anomotaenia nymphaea, характерный паразит у многих куликов региона.

Большой кроншнеп вскрыт в количестве трех особей, и все они были заражены. Найдено 7 видов гельминтов, в том числе цестод - 1 , трематод - 4, нематод - 1 и акантоцефал - 1 вид. Среди них интересна редкая трематода Schistogonimus rarus, которая не обнаружена у прочих видов птиц региона. Она считается специфическим видом паразита у гусеобразных, но, кроме того, найдена у некоторых рыбоядных птиц [Рыжиков, 1967; Сонин, 1985; Сербина, 2008]. У большого кроншнепа обнаружена не определенная до вида акантоцефала Polymorphus gen. sp.

Подсемейство улитов в фауне Байкальской Сибири насчитывает 10 видов, большинство которых гнездится (7 видов), другие отмечаются на пролете. Все виды улитов держатся исключительно около воды, добывают корм по берегам водоемов или в мелководье. При этом места кормления и питание отдельных видов заметно отличаются (Бадмаева, 2014). В осеннем рационе щеголя в устье р. Сармы на Малом море содержалось значительное количество моллюсков - 36,3\% от объема пищевого комка. Среди насекомых ведущее место принадлежит плавунцам, имаго и личинкам. Они в сумме составляют почти половину рациона. Сухопутные насекомые - долгоносики - представлены в незначительном количестве $(8,7 \%)$ по объему [Пыжьянов, Соколовская, Дубешко, 2013]. Перевозчик обычно держится около берегов быстро текущих рек и речек, остальные виды питаются чаще у берегов озер и иногда около медленно текущих рек. Добычей их становятся в основном различные насекомые и их личинки, реже пауки, черви и моллюски. Растительная пища встречается в исключительных случаях. В дельте р. Селенги в желудках больших улитов, добытых в конце сентября, в основном обнаружены моллюски (80-90\% по объему), остатки насекомых и позвонки мелкой рыбы. У фифи насекомые составляли 100\% объема пищи в желудке, пауки и моллюски - 36\%. Из насекомых преобладали водомерки, водолюбы, плавунцы и их личинки, мухи, личинки хирономид и комаров-долгоножек. Близкий к фифи рацион зарегистрирован у поручейника - насекомые (хирономиды, плавунцы, мухи, водомерки, жужелицы и их личинки) составляли $92 \%$ объема пищи в желудке, часто встречались моллюски и редко — пауки (Фефелов и др., 2011). 
Вскрыто 8 видов, среди которых щеголь, поручейник, большой улит и фифи были представлены достаточно большим числом особей. Зараженность птиц данной группы отражена в таблице 4.

Щеголь был представлен 21 экземпляром, но зараженными оказались всего две особи $(9,5 \%)$. Это, пожалуй, самая низкая интенсивность зараженности у исследованных птиц. Обнаружено 8 видов паразитов: цестод - 2 , трематод - 3 , нематод - 3. Из трематод Cyclocoelum brasilianum и C. microstomum не выявлены у других птиц региона. Остальные виды паразитов были обычными у многих видов ржанковых птиц.

Таблий 4

Гельминты подсемейства улитов в Байкальской Сибири

\begin{tabular}{|c|c|c|c|c|c|c|c|c|}
\hline Виды & 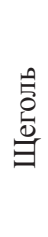 & 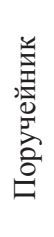 & 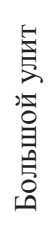 & $\begin{array}{l}\text { 目 } \\
\text { 兽 } \\
\text { 帘 }\end{array}$ & 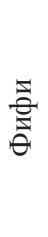 & 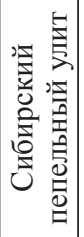 & 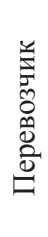 & 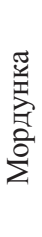 \\
\hline \multicolumn{9}{|c|}{ Цестоды Cestoda } \\
\hline Pseudanomotaenia paramicrorhyncha (Bloch, 1779) & & & & & + & + & & \\
\hline Anomotaenia clavigera $($ Krabbe, 1869$)$ & & & + & & + & & + & \\
\hline Anomotaenia globulus (Wedl, 1855) & & & & + & & + & + & \\
\hline Anomotaenia nymphaea (Schrank, 1790) & & & & & & + & + & \\
\hline Anamotaenia mollis (Volz, 1900) & & & & & & + & & \\
\hline Anomotaenia citrus (Krabbe, 1869) & + & & + & & + & + & + & + \\
\hline Anomotaenia tringae (Burt, 1940) & & & + & & + & + & & \\
\hline Dichoanotaenia tringae (Burt, 1940) & & + & & & & & & \\
\hline Kowalewskiella cingulifera (Krabbe, 1869) & & & + & & + & + & + & \\
\hline Kowalewskiella longiannulata (Baczynska, 1914) & & + & & & & & + & \\
\hline Aploparaksis crassirostris (Krabbe, 1869) & & & & & & & + & + \\
\hline Aploparaksis hirsuta (Krabbe, 1882) & & & & & & & + & \\
\hline Aploparaksis sachalinensis (Krotov, 1952) & + & & + & + & + & + & & \\
\hline Aploparaksis sanjuanensis (Tubangui et Masilungan, 1937) & & & + & & + & & & + \\
\hline Aploparaksis secessivus (Gubanov et Mamaev, 1959) & & & & & & & + & \\
\hline Aploparaksis filum (Goeze, 1782) & & & & & & & + & + \\
\hline Echinocotyle nitida (Clerc, 1902, 1903) & & & & & & & + & \\
\hline Nadejdolepis nitida (Krabbe, 1869) & & & & & & & + & \\
\hline Passerilepis crenata (Goeze, 1782) & & & & & & & + & \\
\hline \multicolumn{9}{|c|}{ Трематоды Trematoda } \\
\hline Cyclocoelum brasilianum (Stossich, 1829) & + & & & & & & & \\
\hline Cyclocoelum microstomum (Creplin, 1829) & + & & & & & & & \\
\hline Cyclocoelum tringae (Stossich, 1902) & & + & & & & & & \\
\hline Cyclocoelum orientale (Skrjabin, 1913) & & + & & & & & & \\
\hline
\end{tabular}


Ц. З. Доржиев, Е. Н. Бадмаева, Ж. Н. Дугаров. Эколого-фаунистический анализ гельминтов водноболотных птиц Байкальской Сибири: 2. Ржанковые Charadrii

\begin{tabular}{|c|c|c|c|c|c|c|c|c|}
\hline Виды & 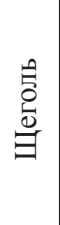 & 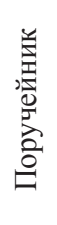 & 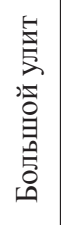 & $\begin{array}{l}\text { 目 } \\
\text { 总 } \\
\text { 尊 }\end{array}$ & $\begin{array}{l}\vec{\theta} \\
\vec{\theta}\end{array}$ & 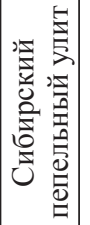 & 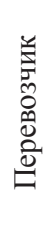 & 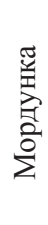 \\
\hline Cyclocoelum mutabile (Zeder, 1800) & & + & + & + & + & & + & \\
\hline Uvitellina vanelli (Rudolphi, 1819) & & & + & & & & & \\
\hline Cotylurus cornutus (Rudolphi, 1808) & & & & & + & & & \\
\hline Diplostomum gasterostei (Williams, 1966) & & & & + & & & & \\
\hline Diplostomum mergi (Dubois, 1932) & & & & + & & & + & \\
\hline Echinoparyphium aconiatum (Dietz, 1909) & & & & + & + & & & \\
\hline Echinoparyphium recurvatum (Linstow, 1873) & & & & + & & & & \\
\hline Echinoparyphium clerci (Skrjabin, 1915) & & + & & + & & & & \\
\hline Echinoparyphium nordiana (Baschkirova, 1941) & & & & + & + & & & \\
\hline Echinoparyphium politum $\quad$ (Skrjabin, 1915) & & & & + & + & & & + \\
\hline Echinostoma revolutum (Fröhlich, 1802) & & & & & & & & + \\
\hline Leucochloridium actitis (McIntosh, 1932) & & & + & & + & & + & \\
\hline Longicollia echinata (Bychowskaja-Pawlowskaja, 1953) & & + & & & & & & \\
\hline Notocotylus linearis (Rudolphi, 1819) & & & & + & + & & & + \\
\hline Plagiorchis nanus (Rudolphi, 1802) & + & & + & + & + & & + & + \\
\hline Plagiorchis uhlwormi (Massino, 1927) & & & & & & & + & \\
\hline Plagiorchis vitellatus (Linstow, 1875) & & & & + & + & + & + & + \\
\hline Plagiorchis nyrocae (Ryjikov et Timofeeva, 1962) & & & & & & & & + \\
\hline Prosthogonimus cuneatus (Rudolphi, 1809 & & & + & + & & & & \\
\hline Prosthogonimus ovatus (Rudolphi, 1803) & & & & + & + & & & \\
\hline Tanaisia fedtschenkoi (Skrjabin, 1924) & & & & + & + & + & & \\
\hline Parorchis gedoelsti (Skrjabin, 1924) & & & & & & + & & \\
\hline \multicolumn{9}{|c|}{ Нематоды Nematoda } \\
\hline Streptocara crassicauda charadrii (Creplin, 1829) & & & + & & & & & + \\
\hline Strongyloides turkmenica (Kurtieva, 1953) & & & + & + & + & & & + \\
\hline Syngamus anterogonimus (Ryjikov, 1949) & & & + & & + & & & \\
\hline Tetrameres dubia (Travassos, 1917) & + & & + & + & + & + & & + \\
\hline Tetrameres uxorious (Mamaev, 1959) & & & & & & & + & \\
\hline Thominx contorta (Creplin, 1839) & & + & + & & + & & & \\
\hline Thominx limicolae Mamaev, 1959 & & & & & & & + & + \\
\hline Eucoleus trilobus (Linstow, 1875) & & & & & & & + & \\
\hline Cosmocephalus capellae (Yamaguti, 1935) & + & + & & & & & & \\
\hline Cosmocephalus obvelatus (Creplin, 1825) & + & & + & & + & & & \\
\hline Contracaecum spiculigerum (Rudolphi, 1809) & & & + & & + & & & \\
\hline Porrocaecum semiteres (Zeder, 1800) & & & & & & & + & + \\
\hline Porrocaecum ensicaudatum (Zeder, 1800) & & & & & & & + & \\
\hline Schistorophus cornutus (Sobolev, 1943) & & & + & & + & & & + \\
\hline
\end{tabular}


Поручейников было вскрыто 44, из них с гельминтами было 5 (11,4\%) особей. Они были заражены 9 видами гельминтов: цестоды - 2, трематоды 5 , нематоды - 1 . Из цестод не обнаружена у других исследованных видов птиц региона Dichoanotaenia tringae, а из трематод - Cyclocoelum orientale. Паразит Cyclocoelum tringae найден еще у чибиса и большого веретенника.

Исследовано 14 особей большого улита, из них зараженными оказались 8 (57,1\%) экземпляров. Состав гельминтов был достаточно богат (18 видов): цестоды -6 , трематоды -5 , нематоды -7 . Все виды были обычными для многих улитов и других ржанковых, за исключением сосальщика Uvitellina vanelli, который обнаружен еще у чибиса и большого веретенника.

Чернылш был представлен тремя особями, и все они были заражены гельминтами (18 видов): цестоды - 2, трематоды -14 , нематоды - 2 . Только у черныша из ржанковых отметили Diplostomum gasterostei. Трематода Echinoparyphium recurvatum встречена еще только у чибиса. Остальные виды имели более широкий круг хозяев.

Фифи вскрыто 32 особи, экстенсивность инвазии равнялась 84,4\%. Выявлено 25 видов паразитов, в том числе цестод - 7, трематод - 11 , нематод - 7. Все они встречаются у многих других видов ржанковых птиц.

У трех особей сибирского пепельного улита, которые оказались все зараженными, установлено 12 видов гельминтов: цестод -8 , трематод -3 , нематод - 1 . Из них два вида - Anamotaenia mollis и Parorchis gedoelsti - не обнаружены у других улитов, но редко встречались у некоторых ржанковых птиц.

Перевозчиков вскрыто 6 экземпляров, из них 5 (83,3\%) были заражены 24 видами гельминтов: цестод - 13, трематод -6, нематод - 5. При этом 9 видов паразитов не выявлены у других улитов, хотя некоторые из них были найдены у отдельных видов ржанковых птиц. Нематода Tetrameres uxorious не отмечена ни у одного другого вида птиц Байкальской Сибири.

У двух особей мородунки, которые были заражены, обнаружено 16 видов паразитов: цестод - 4, трематод - 6, нематод - 6. Сосальщик Echinostoma revolutum не зарегистрирован у других видов улитов региона, но он найден у некоторых песочников и веретенниковых.

Подсемейство плавунчиковые представлено единственным экземпляром пролетного вида - круглоносым плавунчиком, у которого обнаружено три вида трематод из рода Plagiorchis - P. nanus, P. vitellatus u P. nyrocae (табл. 5). Эти гельминты отмечены у некоторых других видов ржанкоообразных, а также у отдельных представителей прочих групп птиц региона.

Из подсемейства песочников в Байкальской Сибири зарегистрировано 15 видов. Вскрыто особей 7 видов. Все они, за исключением турухтана, на территории региона отмечаются в период миграций [Доржиев, 2011]. Есть только единственная находка гнезда длиннопалого песочника в устье Верхней Ангары [Толчин, Заступов, Сонин, 1977]. Все песочники питаются на земле у берега или в мелководье. По кормодобывательному поведению и местам кормления у разных видов песочников наблюдаются небольшие различия. В рационе преобладают различные насекомые и их личинки, попадаются молюски и растительная пища 
Ц. З. Доржиев, Е. Н. Бадмаева, Ж. Н. Дугаров. Эколого-фаунистический анализ гельминтов водноболотных птиц Байкальской Сибири: 2. Ржанковые Charadrii

в виде семян и ягод. Так, на осеннем пролете у длиннопалого песочника на Малом море обнаружены в равном объеме в желудках 4 птиц личинки комаровдолгоножек и семена болотницы настоящей ( $40 \%$ по объему), остальные $20 \%$ примерно в равных количествах моллюски, имаго ручейников и семена рдестов [Пыжьянов, Соколовская, Дубешко, 2013]. На степных озерах Юго-Западного Забайкалья, например, в период пролета у некоторых видов песочников отмечали незначительную дифференциацию по местам кормления [Бадмаева, Доржиев, Сандакова, 2006]. Гельминтофауна песочников показана в табл. 5.

Было вскрыто 12 особей куликов-воробьев, из них зараженными оказались 11 (91,7\%) птиц. Выявлено 28 видов гельминтов: цестод -15 , трематод -8 и нематод - 5 (табл. 5). При этом 6 видов цестод, 3 - трематод и $3-$ нематод не обнаружены у других видов песочников, возможно, из-за небольшого объема материала. Лентец Aploparaksis brachyphallos выявлен, кроме кулика-воробья, только у белохвостого песочника среди всех исследованных видов птиц Байкальской Сибири.

Таблица 5

Гельминты подсемейства плаванчуков и песочников

в Байкальской Сибири

\begin{tabular}{|c|c|c|c|c|c|c|c|c|}
\hline \multirow[b]{2}{*}{ Виды } & \multirow[b]{2}{*}{ 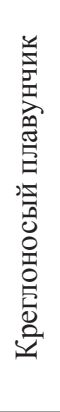 } & \multicolumn{7}{|c|}{ Песочники } \\
\hline & & 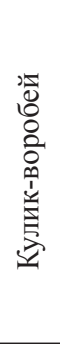 & 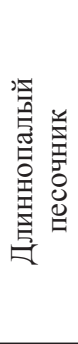 & 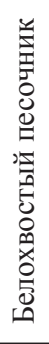 & 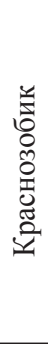 & 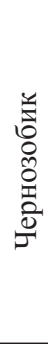 & 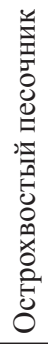 & 苃 \\
\hline \multicolumn{9}{|c|}{ Цестоды Cestoda } \\
\hline $\begin{array}{l}\text { Pseudanomotaenia paramicrorhyncha (Bloch, } \\
\text { 1779) }\end{array}$ & & & & & + & & & + \\
\hline Anomotaenia globulus (Wedl, 1855) & & + & & & & & & \\
\hline Anomotaenia nymphaea (Schrank, 1790) & & + & & & & & & \\
\hline Anomotaenia citrus (Krabbe, 1869) & & + & & & & & & \\
\hline Anomotaenia tringae (Burt, 1940) & & & & & + & & & + \\
\hline Kowalewskiella cingulifera (Krabbe, 1869) & & + & + & & & & & \\
\hline $\begin{array}{l}\text { Trichocephaloides megalocephala (Krabbe, } \\
\text { 1869) }\end{array}$ & & + & & + & + & + & & \\
\hline Aploparaksis brachyphallos (Krabbe, 1869) & & + & & + & & & & \\
\hline Aploparaksis crassirostris (Krabbe, 1869) & & + & & + & + & & & + \\
\hline $\begin{array}{l}\text { Aploparaksis diagonalis (Spassky et Bobova, } \\
\text { 1961) }\end{array}$ & & + & & & & + & & \\
\hline Aploparaksis hirsuta (Krabbe, 1882) & & + & & + & & & & \\
\hline
\end{tabular}




\begin{tabular}{|c|c|c|c|c|c|c|c|c|}
\hline \multirow[b]{2}{*}{ Виды } & \multirow[b]{2}{*}{ 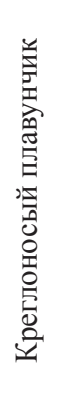 } & \multicolumn{7}{|c|}{ Песочники } \\
\hline & & 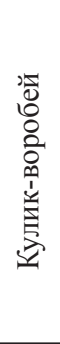 & 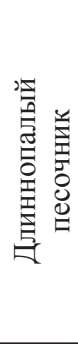 & 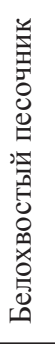 & 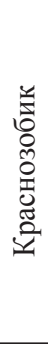 & 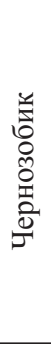 & 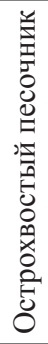 & 焉 \\
\hline Aploparaksis pseudofilum (Clerc, 1902) & & & & + & & & & \\
\hline Aploparaksis sachalinensis Krotov, 1952 & & + & & + & + & & + & \\
\hline A. sanjuanensis Tubangui et Masilungan, 1937 & & + & & & & & + & \\
\hline A. secessivus Gubanov et Mamaev, 1959 & & + & & & & & & \\
\hline Echinocotyle nitida (Clerc, 1902, 1903) & & + & & & & & & \\
\hline Echinocotyle uralensis Clerc, 1902 & & & & & & & & + \\
\hline Nadejdolepis nitida (Krabbe, 1869) & & + & + & + & & & & \\
\hline Proginotaenia odhneri Nybelin, 1919 & & + & & & & & & + \\
\hline \multicolumn{9}{|c|}{ Трематоды Trematoda } \\
\hline Cyclocoelum brasilianum (Stossich, 1829) & & + & & + & + & & & + \\
\hline Cyclocoelum mutabile (Zeder, 1800) & & & & & & & & + \\
\hline Cotylurus cornutus (Rudolphi, 1808) & & + & & & & & & \\
\hline Echinoparyphium aconiatum (Dietz, 1909) & & & & & & & & + \\
\hline Echinoparyphium politum (Skrjabin, 1915) & & + & & + & & & & \\
\hline Echinostoma revolutum (Fröhlich, 1802) & & + & & & & & & + \\
\hline Leucochloridium actitis (McIntosh, 1932) & & & + & & & & & + \\
\hline Plagiorchis nanus (Rudolphi, 1802) & + & & + & & + & & + & + \\
\hline Plagiorchis uhlwormi (Massino, 1927) & & + & & & & & & \\
\hline Plagiorchis vitellatus (Linstow, 1875) & + & + & & & & & & + \\
\hline $\begin{array}{l}\text { Plagiorchis nyrocae (Ryjikov et Timofeeva, } \\
\text { 1962) }\end{array}$ & + & + & & & & & & \\
\hline Prosthogonimus cuneatus (Rudolphi, 1809) & & + & & & & & & + \\
\hline \multicolumn{9}{|c|}{ Нематоды Nematoda } \\
\hline Strongyloides turkmenica (Kurtieva, 1953) & & + & & & & & & \\
\hline Syngamus anterogonimus (Ryjikov, 1949) & & + & & & & & & \\
\hline Syngamus palustris (Ryjikov, 1949) & & & & & & & & + \\
\hline Tetrameres dubia (Travassos, 1917) & & + & & & + & & + & \\
\hline Eucoleus trilobus (Linstow, 1875) & & + & & & & & & \\
\hline Contracaecum spasskyi (Mozgovoy, 1950) & & & + & & + & & & \\
\hline Porrocaecum semiteres (Zeder, 1800) & & + & + & & & & & \\
\hline
\end{tabular}


Ц. З. Доржиев, Е. Н. Бадмаева, Ж. Н. Дугаров. Эколого-фаунистический анализ гельминтов водноболотных птиц Байкальской Сибири: 2. Ржанковые Charadrii

Всего вскрыто две особи длиннопалого песочника и установлено 6 видов паразитов: цестод - 2 , трематод - 2 и нематод -2 , которые отмечены у некоторых других видов птиц региона. Круглый червь Contracaecum spasskyi не обнаружен у других видов ржанковых птиц Байкальской Сибири, кроме краснозобика.

Белохвостый песочник исследован в единственном экземпляре. Он оказался зараженным 8 видами гельминтов, в том числе цестоды -6 , трематоды -2 . Цестода Aploparaksis pseudofilum отмечена только у этого песочника в регионе.

Вскрыто 6 особей краснозобика, и все они были заражены гельминтами (9 видов): цестод - 5, трематод - 2 и нематод - 2 .

Чернозобик попался в единственном экземпляре, он был заражен двумя видами цестод, которые обнаружены у некоторых других видов песочников региона.

Острохвостый песочник также представлен в одном экземпляре, у него обнаружили четыре обычных вида гельминтов: цестод - 2, трематод и нематод - по 1.

У двух вскрытых турухтанов выявлено 14 видов гельминтов: цестод - 5, трематод - 8, нематод - 1 (табл. 5). Четыре вида гельминтов не обнаружены у других песочников. Причем цестода Echinocotyle uralensis и нематода Syngamus palustris выявлены только у этого вида в регионе. Сосальщик Echinoparyphium aconiatum оказался паразитом у некоторых видов уток (Доржиев, Бадмаева, Дугаров, 2019).

Таким образом, результаты исследований гельминтов у 31 вида подотряда ржанковых птиц Байкальской Сибири показали большое их разнообразие и специфичность по группам птиц. У них выявлено 88 видов гельминтов, относящихся к 4 классам и 17 семействам. Наиболее богатым в видовом отношении оказался класс цестод, на долю которых приходится 40,9\%, далее по мере убывания идут трематоды (чуть более одной трети), нематоды (одна пятая часть), скребни представлены одним видом (табл. 6).

Таблица 6

Соотношение разных таксономических групп гельминтов у подотряда ржанковых птиц Байкальской Сибири

\begin{tabular}{|l|c|c|c|}
\hline \multicolumn{1}{|c|}{ Класс } & Число семейств & Число видов & $\begin{array}{c}\text { Соотношение видов } \\
\text { разных классов, \% }\end{array}$ \\
\hline Цестода & 4 & 36 & 40,9 \\
\hline Трематода & 7 & 30 & 34,1 \\
\hline Нематода & 5 & 21 & 23,7 \\
\hline Скребни & 1 & 1 & 1,1 \\
\hline Всего & 17 & 88 & 100 \\
\hline
\end{tabular}

При этом заметно отличается соотношение разных групп паразитов в подсемействах ржанковых птиц (табл. 7). Так, количество видов цестод преобладало у ржанков, бекасовых и песочников, причем у ржанков и бекасовых они составляли более половины видового состава паразитов. Трематоды доминировали у чибисовых, камнешарок, веретенниковых, улитов и плаванчуков, при этом у первых трех подсемейств их доля была выше $50 \%$. Нематоды во всех подсемействах были представлены относительно скромно. Отметим, что по камнешаркам и плавунчикам материал очень маленький и, по всей вероятности, не может отражать истинную картину. 
Количество гельминтов у разных подсемейств ржанковых птиц Байкальской Сибири

\begin{tabular}{|c|c|c|c|c|c|c|}
\hline \multirow[b]{2}{*}{ Подсемейство } & \multirow{2}{*}{$\begin{array}{c}\text { Число } \\
\text { видов } \\
\text { Птиц }\end{array}$} & \multicolumn{5}{|c|}{ Количество видов гельминтов } \\
\hline & & $\begin{array}{c}\text { всего, } \\
\text { абс }\end{array}$ & $\begin{array}{l}\text { цестод, } \\
\text { абс./\% }\end{array}$ & $\begin{array}{c}\text { трематод, } \\
\text { абс. } / \%\end{array}$ & $\begin{array}{c}\text { нематод, } \\
\text { абс. } / \%\end{array}$ & $\begin{array}{c}\text { скребней, } \\
\text { абс. } / \%\end{array}$ \\
\hline Чибисовые & 1 & 24 & $6 / 25$ & $15 / 62,5$ & $3 / 12,5$ & 0 \\
\hline Ржанки & 3 & 27 & $14 / 51,9$ & $8 / 29,6$ & $5 / 18,5$ & 0 \\
\hline Камнешарки & 1 & 3 & 0 & $2 / 66,7$ & $1 / 33,3$ & 0 \\
\hline Бекасовые & 4 & 26 & $14 / 53,8$ & $8 / 30,8$ & $4 / 15,4$ & 0 \\
\hline Веретенниковые & 6 & 20 & $7 / 35$ & $10 / 50$ & $2 / 10$ & $1 / 5$ \\
\hline Улиты & 8 & 59 & $19 / 32,2$ & $26 / 44,1$ & $14 / 23,7$ & 0 \\
\hline Плавунчики & 1 & 3 & - & $3 / 100$ & - & 0 \\
\hline Песочники & 7 & 38 & $19 / 50,0$ & $12 / 31,3$ & $7 / 18,4$ & 0 \\
\hline
\end{tabular}

Число хозяев у разных видов гельминтов составляет от 1 до 18: у цестод 1-10 хозяев, трематод - 1-18, нематод - 1-12. Скребни, как указывали ранее, были представлены одним видом, найденым в большом кроншнепе (табл. 8). В целом наблюдается общая картина во всех классах гельминтов, большинство видов гельминтов имеет $1-3$ хозяина: у цестод $-66,7 \%$, трематод $-60,0$, нематод - 76,2. При этом четвертая часть гельминтов выявлена у одного хозяина, чуть больше - у двух хозяев. Сосальщики по сравнению с другими классами обладают несколько большим числом хозяев, в частности, доля видов, паразитирующих у 5 хозяев, достигала $13,3 \%$.

Таблииа 8

Соотношение гельминтов, имеющих разное количество хозяев - ржанковых птиц в Байкальской Сибири

\begin{tabular}{|c|c|c|c|c|c|c|c|c|c|c|}
\hline \multirow{2}{*}{$\begin{array}{c}\text { Классы } \\
\text { гельминтов } \\
\text { (число видов) }\end{array}$} & \multicolumn{10}{|c|}{$\begin{array}{c}\text { Число видов гельминтов в одном хозяине и соотношение количества (\%) видов } \\
\text { птиц с указанным числом паразитов }\end{array}$} \\
\hline & 1 & 2 & 3 & 4 & 5 & 6 & 7 & 8 & 9 & $\begin{array}{l}10 \text { и } \\
\text { более }\end{array}$ \\
\hline \multirow{2}{*}{ Цестоды (36) } & 11 & 10 & 3 & 3 & 1 & 1 & 1 & 2 & 2 & 2 \\
\hline & 30,6 & 27,8 & 8,3 & 8,3 & 2,8 & 2,8 & 2,8 & 5,5 & 5,5 & 5,5 \\
\hline \multirow{2}{*}{ Трематоды (30) } & 3 & 10 & 5 & 2 & 4 & \multirow{2}{*}{0} & 1 & 2 & \multirow{2}{*}{0} & 3 \\
\hline & 10,0 & 33,3 & 16,7 & 6,7 & 13,3 & & 3,3 & 6,7 & & 10,0 \\
\hline \multirow[b]{2}{*}{ Нематоды (21) } & 5 & 5 & 6 & 1 & 1 & 1 & \multirow[b]{2}{*}{0} & \multirow[b]{2}{*}{0} & \multirow[b]{2}{*}{0} & 2 \\
\hline & 23,8 & 23,8 & 28,6 & 4,8 & 4,8 & 4,8 & & & & 9,5 \\
\hline Скребни (1) & 100 & - & - & - & - & - & - & - & - & - \\
\hline
\end{tabular}


Ц. З. Доржиев, Е. Н. Бадмаева, Ж. Н. Дугаров. Эколого-фаунистический анализ гельминтов водноболотных птиц Байкальской Сибири: 2. Ржанковые Charadrii

Среди цестод наибольший круг хозяев (около 10) имеют Aploparaksis sachalinensis, Anomotaenia tringae, Aploparaksis crassirostris, Anomotaenia citrus и некоторые другие. У трематод очень широко распространена Plagiorchis nanus (18 хозяев), далее идут Cyclocoelum mutabile, Leucochloridium actitis, Echinoparyphium politum, Plagiorchis vitellatus, которые найдены у 8-11 видов ржанковых птиц. Среди нематод есть несколько видов (Tetrameres dubia Porrocaecum semiteres), паразитирующих у более 10 видов птиц (табл. 9).

Таблиия 9

Таксономический состав гельминтов у ржанковых птиц и распределение их по хозяевам в Байкальской Сибири

\begin{tabular}{|c|c|c|}
\hline & \multicolumn{2}{|r|}{ Хозяева — ржанковые птицы } \\
\hline & $\begin{array}{l}\text { Кол-во } \\
\text { видов }\end{array}$ & Виды птиц \\
\hline \multicolumn{3}{|c|}{ Класс Цестоды Cestoda } \\
\hline \multicolumn{3}{|l|}{ Семейство Dilepididae } \\
\hline Dilepis undula & 1 & кроншнеп-малютка \\
\hline Panuwa guiarti & 1 & малый зуек \\
\hline Polycercus paradoxa & 2 & малый зуек, азиатский бекас \\
\hline Nototaenia brevis & 1 & бурокрылая ржанка \\
\hline $\begin{array}{l}\text { Pseudanomotaenia } \\
\text { paramicrorhyncha }\end{array}$ & 6 & $\begin{array}{l}\text { малый зуек, азиатский бекас, сибирский пепельный } \\
\text { улит, фифи, краснозобик, турухтан }\end{array}$ \\
\hline \multicolumn{3}{|l|}{ Семейство Choanotaeniidae } \\
\hline Anomotaenia clavigera & 4 & малый зуек, большой улит, фифи, перевозчик \\
\hline Anomotaenia microphallos & 2 & чибис, бурокрылая ржанка \\
\hline Anomotaenia microrhyncha & 1 & чибис \\
\hline Anomotaenia globulus & 5 & $\begin{array}{l}\text { бурокрылая ржанка, черныш, сибирский пепельный } \\
\text { улит, перевозчик, кулик-воробей }\end{array}$ \\
\hline Anomotaenia nymphaea & 6 & $\begin{array}{l}\text { кроншнеп-малютка, средний кроншнеп, большой } \\
\text { кроншнеп, сибирский пепельный улит, перевозчик, } \\
\text { кулик-воробей }\end{array}$ \\
\hline Anomotaenia ancora & 1 & азиатский бекас \\
\hline Anamotaenia mollis & 2 & галстучник, сибирский пепельный улит \\
\hline Anomotaenia citrus & 10 & $\begin{array}{l}\text { малый зуек, вальдшнеп, азиатский бекас, щеголь, } \\
\text { большой улит, фифи, сибирский пепельный улит, } \\
\text { перевозчик, мородунка, кулик-воробей }\end{array}$ \\
\hline Anomotaenia stentorea & 1 & чибис \\
\hline Anomotaenia tringae & 9 & $\begin{array}{l}\text { чибис, галстучник, малый зуек, азиатский бекас, } \\
\text { большой улит, фифи, сибирский пепельный улит, } \\
\text { краснозобик, турухтан }\end{array}$ \\
\hline Dichoanotaenia tringae & 1 & поручейник \\
\hline Kowalewskiella cingulifera & 8 & $\begin{array}{l}\text { малый зуек, вальдшнеп, большой улит, фифи, } \\
\text { сибирский пепельный улит, перевозчик, кулик- } \\
\text { воробей, длиннопалый песочник }\end{array}$ \\
\hline Kowalewskiella longiannulata & 2 & поручейник, перевозчик \\
\hline Trichocephaloides megalocephala & 4 & $\begin{array}{l}\text { кулик-воробей, белохвостый песочник, } \\
\text { краснозобик, чернозобик }\end{array}$ \\
\hline
\end{tabular}




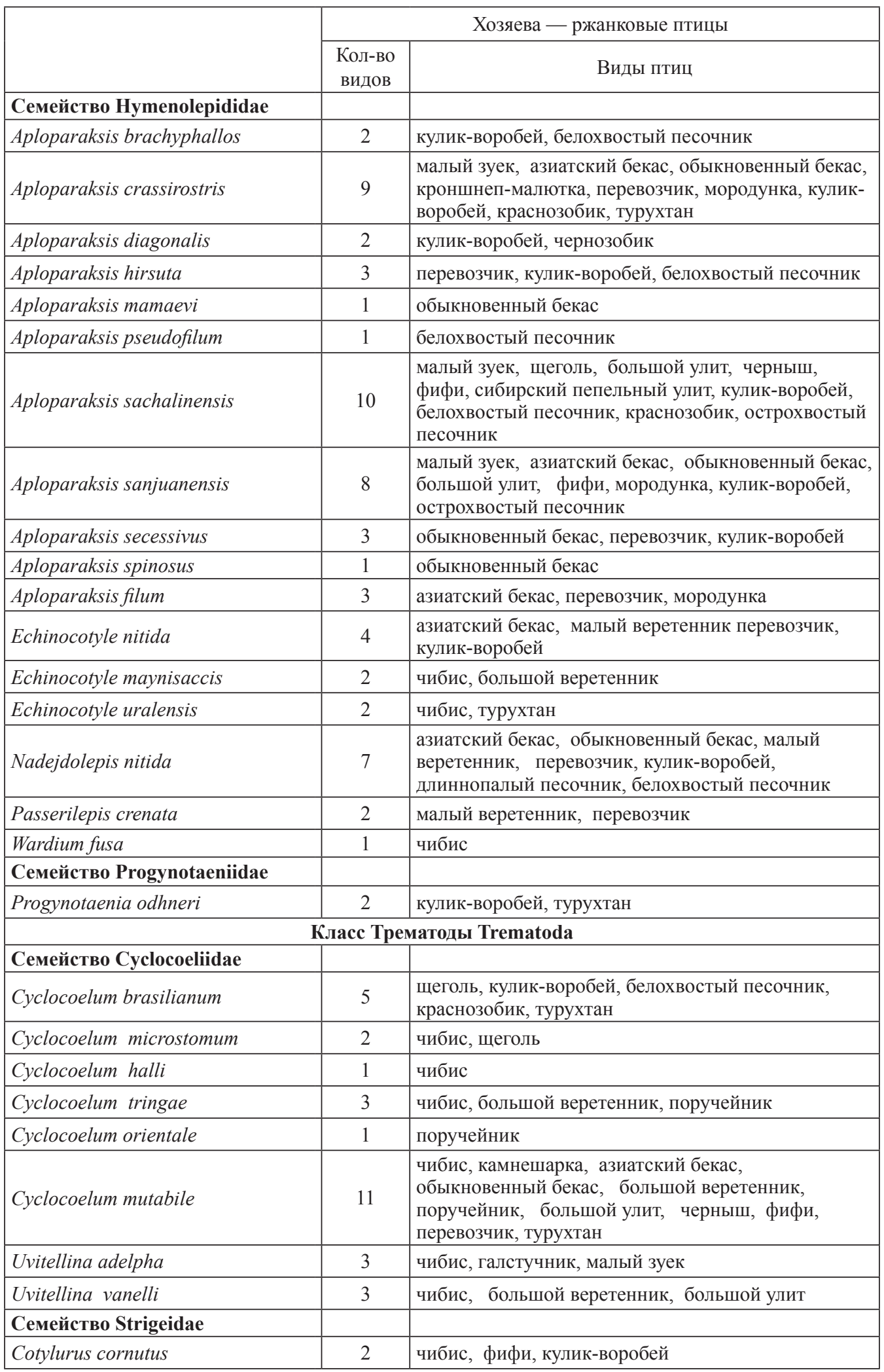


Ц. З. Доржиев, Е. Н. Бадмаева, Ж. Н. Дугаров. Эколого-фаунистический анализ гельминтов водноболотных птиц Байкальской Сибири: 2. Ржанковые Charadrii

\begin{tabular}{|c|c|c|}
\hline \multirow{3}{*}{\begin{tabular}{|l} 
\\
Семейство Diplostomidae \\
\end{tabular}} & \multicolumn{2}{|r|}{ Хозяева - ржанковые птицы } \\
\hline & $\begin{array}{c}\text { Кол-во } \\
\text { видов }\end{array}$ & \multirow[t]{2}{*}{ Виды птиц } \\
\hline & & \\
\hline Diplostomum gasterostei & 1 & черныш \\
\hline Diplostomum mergi & 2 & черныш, перевозчик \\
\hline \multicolumn{3}{|l|}{ Семейство Echinostomatidae } \\
\hline Echinoparyphium aconiatum & 2 & черныш, фифи, турухтан \\
\hline Echinoparyphium recurvatum & 2 & чибис, черныш \\
\hline Echinoparyphium leric & 2 & чибис, поручейник, черныш \\
\hline Echinoparyphium nordiana & 3 & чибис, черныш, фифи \\
\hline Echinoparyphium politum & 8 & $\begin{array}{l}\text { азиатский бекас, обыкновенный бекас, черныш, } \\
\text { фифи, мородунка, кулик-воробей, белохвостый } \\
\text { песочник, турухтан }\end{array}$ \\
\hline Echinostoma paraulum & 2 & чибис, большой веретенник \\
\hline Echinostoma revolutum & 4 & $\begin{array}{l}\text { кроншнеп-малютка, мородунка, кулик-воробей, } \\
\text { турухтан }\end{array}$ \\
\hline Echinostoma stantschinskii & 2 & азиатский бекас, лесной дупель \\
\hline Longicollia echinata & 5 & $\begin{array}{l}\text { чибис, азиатский бекас, обыкновенный бекас, } \\
\text { большой веретенник, поручейник } \\
\end{array}$ \\
\hline \multicolumn{3}{|l|}{ Семейство Leucochloridiidae } \\
\hline Leucochloridium actitis & 10 & $\begin{array}{l}\text { чибис, малый зуек, азиатский бекас, кроншнеп- } \\
\text { малютка, большой кроншнеп, большой улит, } \\
\text { фифи, перевозчик, длиннопалый песочник, } \\
\text { турухтан }\end{array}$ \\
\hline \multicolumn{3}{|l|}{ Семейство Notocotylidae } \\
\hline Notocotylus linearis & 3 & чибис, черныш, фифи, мородунка \\
\hline \multicolumn{3}{|l|}{ Семейство Plagiorchiidae } \\
\hline Plagiorchis nanus & 18 & $\begin{array}{l}\text { галстучник, малый зуек, азиатский бекас, } \\
\text { обыкновенный бекас, малый веретенник, } \\
\text { кроншнеп-малютка, большой кроншнеп, щеголь, } \\
\text { большой улит, черныш, фифи, перевозчик, } \\
\text { мородунка, круглоносый плавунчик, длиннопалый } \\
\text { песочник, краснозобик, острохвостый песочник, } \\
\text { турухтан }\end{array}$ \\
\hline Plagiorchis uhlwormi & 5 & $\begin{array}{l}\text { большой веретенник, кроншнеп-малютка, } \\
\text { большой кроншнеп, перевозчик, кулик-воробей }\end{array}$ \\
\hline Plagiorchis vitellatus & 8 & $\begin{array}{l}\text { черныш, фифи, сибирский пепельный улит, } \\
\text { перевозчик, мородунка, круглоносый плавунчик, } \\
\text { кулик-воробей, турухтан }\end{array}$ \\
\hline Plagiorchis nyrocae & 4 & $\begin{array}{l}\text { галстучник, мородунка, круглоносый плавунчик, } \\
\text { кулик-воробей }\end{array}$ \\
\hline \multicolumn{3}{|l|}{ Семейство Prosthogonimidae } \\
\hline Prosthogonimus cuneatus & 5 & $\begin{array}{l}\text { обыкновенный бекас, большой улит, черныш, } \\
\text { кулик-воробей, турухтан }\end{array}$ \\
\hline Prosthogonimus ovatus & 2 & чибис, черныш, фифи \\
\hline Schistogonimus rarus & & большой кроншнеп \\
\hline \multicolumn{3}{|l|}{ Семейство Eucotylidae } \\
\hline Tanaisia fedtschenkoi & 7 & $\begin{array}{l}\text { галстучник, малый зуек, азиатский бекас, } \\
\text { обыкновенный бекас, черныш, фифи, сибирский } \\
\text { пепельный улит }\end{array}$ \\
\hline
\end{tabular}




\begin{tabular}{|c|c|c|}
\hline \multirow{3}{*}{ Семейство Parorchidae } & \multicolumn{2}{|r|}{ Хозяева - ржанковые птицы } \\
\hline & $\begin{array}{l}\text { Кол-во } \\
\text { видов }\end{array}$ & Виды птиц \\
\hline & & \\
\hline Parorchis gedoelsti & 2 & камнешарка, сибирский пепельный улит \\
\hline \multicolumn{3}{|c|}{ Класс Нематоды Nematoda } \\
\hline \multicolumn{3}{|l|}{ Семейство Acuariidae } \\
\hline Streptocara crassicauda charadrii & 2 & большой улит, мородунка \\
\hline Strongyloides turkmenica & 6 & $\begin{array}{l}\text { камнешарка, большой улит, черныш, фифи, } \\
\text { мородунка, кулик-воробей }\end{array}$ \\
\hline Syngamus anterogonimus & 3 & большой улит, фифи, кулик-воробей \\
\hline Syngamus gibbocephalus & 3 & вальдшнеп, азиатский бекас, обыкновенный бекас \\
\hline Syngamus palustris & 1 & турухтан \\
\hline \multicolumn{3}{|l|}{ Семейство Tetrameridae } \\
\hline Tetrameres dubia & 12 & $\begin{array}{l}\text { галстучник, вальдшнеп, азиатский бекас, щеголь, } \\
\text { большой улит, черныш, фифи, сибирский } \\
\text { пепельный улит, мородунка, кулик-воробей, } \\
\text { краснозобик, острохвостый песочник }\end{array}$ \\
\hline Tetrameres fissispina & 1 & чибис \\
\hline Tetrameres numenii & 1 & большой кроншнеп \\
\hline Tetrameres uxorious & 1 & перевозчик \\
\hline Tetrameres limicollis & 3 & вальдшнеп, азиатский бекас, обыкновенный бекас \\
\hline \multicolumn{3}{|l|}{ Семейство Capillariidae } \\
\hline Thominx contorta & 3 & поручейник, большой улит, фифи \\
\hline Thominx limicolae & 3 & бурокрылая ржанка, перевозчик, мородунка \\
\hline Eucoleus trilobus & 4 & галстучник, малый зуек, перевозчик, кулик-воробей \\
\hline \multicolumn{3}{|l|}{ Семейство Amidostomidae } \\
\hline Amidostomum henryi & 1 & чибис \\
\hline \multicolumn{3}{|l|}{ Семейство Acuariidae } \\
\hline Cosmocephalus capellae & 2 & щеголь, поручейник \\
\hline Cosmocephalus obvelatus & 5 & $\begin{array}{l}\text { азиатский бекасовидный веретенник, большой } \\
\text { веретенник, щеголь, большой улит, фифи }\end{array}$ \\
\hline Schistorophus cornutus & 3 & большой улит, фифи, мородунка \\
\hline \multicolumn{3}{|l|}{ Семейство Anisakidae } \\
\hline Contracaecum spasskyi & 2 & длиннопалый песочник, краснозобик \\
\hline Contracaecum spiculigerum & 2 & большой улит, фифи \\
\hline Porrocaecum semiteres & 10 & $\begin{array}{l}\text { чибис, бурокрылая ржанка, галстучник, вальдшнеп, } \\
\text { азиатский бекас, обыкновенный бекас, перевозчик, } \\
\text { мородунка, кулик-воробей, длиннопалый песочник }\end{array}$ \\
\hline Porrocaecum ensicaudatum & 2 & чибис, перевозчик \\
\hline \multicolumn{3}{|c|}{ Класс Акантоцефала Acanthacephala } \\
\hline Семейство Polymorphidae & & \\
\hline Polymorphus gen. sp. & 1 & большой кроншнеп \\
\hline
\end{tabular}


Ц. З. Доржиев, Е. Н. Бадмаева, Ж. Н. Дугаров. Эколого-фаунистический анализ гельминтов водноболотных птиц Байкальской Сибири: 2. Ржанковые Charadrii

Попытались выявить различие в гельминтофауне гнездящихся и пролетных видов ржанковых птиц. В этом плане четкой дифференциации нет.

Специфичность гельминтофауны по подсемействам хозяев рассмотрена на примере видов, представленных 8 и более особями. Таковых набралось 8 видов, относящихся к 5 подсемействам (подсемейство чибисовые представляет чибис, бекасовые - бекас; веретенниковые - большой веретенник; улиты - щеголь, поручейник, большой улит и фифи; песочники - кулик-воробей). Как видно из данных, приведенных в таблице 10 , коэффициент сходства, расчитанный по Серенсену, показывает, что гельминтофауна разных подсемейств заметно отличается и он в целом низкий.

Таблица 10

Сравнение видового состава гельминтов разных подсемейств ржанковых птиц Байкальской Сибири по индексу Серенсена

\begin{tabular}{|c|c|c|c|c|c|}
\hline & 4 & Б & $B$ & y & $\Pi$ \\
\hline 4 & 100 & 8,1 & 22,2 & 22,0 & 3,9 \\
\hline $\bar{E}$ & 8,1 & 100 & 10,0 & 13,3 & 19,4 \\
\hline$B$ & 22,2 & 10,0 & 100 & 15,8 & 2,9 \\
\hline$y$ & 22,0 & 13,3 & 15,8 & 100 & 20,8 \\
\hline$\Pi$ & 3,9 & 19,4 & 2,9 & 20,8 & 100 \\
\hline
\end{tabular}

Обозначения: подсемейства ржанковых птиц: 4 - чибисовые; 5 - бекасовые, $B-$ веретенниковые, $У$ - улиты, $\Pi$ - песочники

Так, коэффициент сходства гельминтов чибиса и большого веретенника, представителей разных подсемейств, оказался низким - 8,1\%. При этом общих видов насчитано всего 3 (две трематоды и одна нематода). Еще низким этот показатель оказался у чибиса и кулика-воробья - 3,9\%. У них общих видов зарегистрировано по одному из класса сосальщиков и круглых червей. У чибиса с веретенниками и улитами коэффициент сходства гельминтов было несколько выше.

Коэффициент сходства гельминтов у обыкновенного бекаса с представителями других подсемейств оказался относительно низким: с большим веретенником - 10\% (общих только два вида трематод), с четырьмя видами улитов $13,3 \%$ (общих один вид цестоды и 5 видов трематод), куликом-воробьем - 19,4\% (общих цестод оказалось 4 вида, трематод - 1, нематод - 1). Нужно заметить, что у азиатского бекаса отмечали других общих видов с представителями других подсемейств ржанковых птиц (табл. 9).

У большого веретенника по сравнению с другими группами птиц относительно высокий коэффициент сходства гельминтов отмечен с чибисом и улитами, у кулика-воробья - с бекасом и улитами.

В целом, как видно, коэффициент сходства гельминтов у разных подсемейств ржанковых птиц низкий и редко превышает $20 \%$. Это связано с имеющимися различиями в питании, кормодобывательном поведении и использовании кормовых биотопов и микростаций. 


\section{Заключение}

Эколого-фаунистический анализ гельминтов ржанковых птиц Байкальской Сибири позволяет отметить следующее. Данная группа птиц весьма привлекательна не только тем, что она в видовом отношении богата, но и многие виды распространены очень широко по всему миру, гнездовые и зимовочные ареалы их расположены на значительном расстоянии и птицы во время миграций посещают территории различных континентов и природных зон. В этом плане ржанковые птицы, как и другие мигранты, имеют особое значение в распространении различных паразитов.

Из 58 видов подотряда ржанковых птиц региона удалось исследовать чуть больше половины (31), причем по многим видам материал оказался небольшим. Поэтому продолжение гельминтологических исследований водно-болотных птиц остается актуальным. Однако же в Сибири такие исследования проводятся очень редко.

Гельминтофауна ржанковых птиц оказалась богатой (88 видов из 4 классов и 17 семейств), причем цестод отмечалось больше (40,9\% видового богатства), трематод - чуть более одной трети $(34,1)$, нематод - одна пятая часть $(23,7)$, скребней - единицы $(1,1)$.

Однако же соотношение представителей разных классов паразитов у разных подсемейств ржанковых птиц заметно отличалось. У отдельных подсемейств (ржанков, бекасовых и песочников) преобладали цестоды, у других (чибисовых, камнешарок, веретенниковых, улитов и плавунчиковых) — трематоды.

Большое число паразитов имели такие виды, как кулик-воробей, фифи, мородунка. Широкое распространение среди ржанковых птиц имели цестоды Aploparaksis sachalinensis, Anomotaenia tringae, Aploparaksis crassirostris, Anomotaenia citrus, трематоды Plagiorchis nanus, Cyclocoelum mutabile, Leucochloridium actitis, Echinoparyphium politum, Plagiorchis vitellatus, нематоды Tetrameres dubia Porrocaecum semiteres. Выявлено немало специфических для ржанковых птиц гельминтов ( род Anomotaenia - A. citrus, A. globulus, A. tringae u dp., Pseudanomotaenia paramicrorhyncha, Trichocephaloides megalocephala, Aploparaksis sachalinensis и др.).

Гельминтофауна разных подсемейств ржанковых птиц имела относительно небольшое сходство, что объясняется различиями в питании, кормодобывательном поведении и местах кормления.

\section{Литература}

Аниканова В. С., Беспятова Л. А., Бугмырин С. В. Паразиты обыкновенной бурозубки (Sorex araneus L.) Южной Карелии // Эколого-паразитологические исследования животных и растений Европейского Севера. Петрозаводск, 2001. C. $78-85$.

Бадмаева Е. Н. Пространственная дифференциация куликов в местах кормовых скоплений (экологические ниши Charadriiformes) // Зоологические чтения 2014 : материалы всерос. науч.-практ. конф. с междунар. участием (Новосибирск, 11 апреля 2014 г.) / под ред. А. В. Сахарова, Л. А. Ишигеновой; Мин-во образования и науки РФ, Новосиб. гос. пед. ун-т. Новосибирск: Изд-во НГПУ, 2014. C. 205-211. 
Ц. З. Доржиев, Е. Н. Бадмаева, Ж. Н. Дугаров. Эколого-фаунистический анализ гельминтов водноболотных птиц Байкальской Сибири: 2. Ржанковые Charadrii

Бадмаева Е. Н., Доржиев Ц. З., Сандакова С. Л. Пространственные взаимоотношения куликов в местах кормовых скоплений на степных озерах Юго-Западного Забайкалья // Современные проблемы орнитологии Сибири и Центральной Азии: в 2 ч. / отв. ред. Ц. 3. Доржиев. Улан-Удэ: Изд-во Бурят. гос. ун-та, 2006. Вып. 6, ч. 2. С. 35-42.

Дзармотова 3. И., Плиева А. М. Экологические особенности распространения гельминтов синантропных птиц // Юг России: экология, развитие. 2012. № 2. С. $37-41$.

Доржиев Ц. 3. Птицы Байкальской Сибири: систематический состав, характер пребывания и территориальное размещение // Байкальский зоологический журнал. 2011. № 1(6). C. $30-55$.

Доржиев Ц. 3., Бадмаева Е. Н. Неворобьиные Non-Passeriformes птицы Республики Бурятия: аннотированный список // Природа Внутренней Азии. Nature of Inner Asia. 2016. № 1(1). C. 7-60.

Доржиев Ц. 3., Бадмаева Е. Н., Дугаров Ж. Н. Эколого-фаунистический анализ гельминтов водно-болотных птиц Байкальской Сибири: 1. Утиные Anatidae // Природа Внутренней Азии. Nature of Inner Asia. 2019. № 1(10). С. 7-27.

Меркушева И. В., Бобкова А. Ф. Гельминты домашних и диких животных Белоруссии : каталог. Минск, 1981. 120 с.

Некрасов А. В. Гельминты диких птиц бассейна озера Байкал. Улан-Удэ: Изд-во БНЦ CO РAH, 2000. $56 \mathrm{c}$.

Пенкина О. Л., Ушакова Е. Л., Иванюшина А. М., Чеботарева Т. Ю. Зараженность гельминтами диких водоплавающих птиц в Омской области // Вестник КрасГАУ. 2017. № 2. C. 260-264.

Пыжьянов С. В., Соколовская Е. А., Дубешко Л. Н. Трофические связи куликов на Малом море (Средний Байкал) в период осенних миграций // Байкальский зоологический журнал. 2013. № 2(13). С. 101-105.

Рыжиков К. М. Определитель гельминтов домашних водоплавающих птиц. М.: Наука, 1967. - 265 с.

Сербина Е. А. Особенности сезонного развития Schistogonimus rarus (Trematoda: Prosthogonimidae). Опыт количественной оценки трематод в экосистеме озера Малые Чаны (юг Западной Сибири) // Паразитология. 2008. Т. 42, вып. 1. С. 53-65.

Сонин М. Д. Определитель трематод рыбоядных птиц Палеарктики. М. : Наука, 1985. $256 \mathrm{c}$.

Толчин В. А., Заступов В. П., Сонин В. Д. Материалы к познанию фауны Байкала // Орнитология. М., 1977. Вып. 13. С. 40-48.

Тупицын И. И., Тимошенко Т. М. О куликах дельты реки Селенги (разнообразие, численность, гельминты). Сохранение биологического разнообразия в Байкальском регионе: проблемы, подходы, практика. Улан-Удэ: Изд-во БНЦ СО РАН, 1996. Т. 2. С. 32-34.

Фефелов И. В., Тупицын И. И., Подковыров В. А., Журавлев В. Е. Птицы дельты Селенги. Иркутск, 2001. 320 с.

Юшков В. Ф. Гельминты млекопитающих. СПб., 1995. 201 с. (Фауна европейского северо-запада России; т. 3).

Danzan G. Helminth Fauna of Domestic and Wild Birds of Mongolia // Proceedings of the All Union Institute for Helminthology named after K. S. Skryabin (VIGIS). 1964. No. 11. P. 42-44.

Ganzorig S. Check List of Gelminth Parasites of Mongolian Birds // Ornis Mongolica. 2016. V. 4(432). P. 3-28.

Ganzorig S., Danzan G. Materials on the helminth fauna of the birds in Huvsgul region // Natural Condition and Resources of Some Regions of Mongolia. Ulaanbaatar, 1990. P. 111-112. 


\section{ECOLOGICAL AND FAUNISTIC ANALYSIS OF HELMINTS \\ IN WETLAND BIRDS OF BAIKAL SIBERIA: \\ 2. CHARADRII}

Ts. Z. Dorzhiev, E. N. Badmaeva, Zh. N. Dugarov

Tsydypzhap Z. Dorzhiev

Dr. Sci. (Biol.), Prof.,

Dorzhi Banzarov Buryat State University

24a Smolina St., Ulan-Ude 670000, Russia

E-mail: tsydypdor@mail.ru

Evgeniya N. Badmaeva

Cand. Sci. (Biol.), A/Prof.,

Dorzhi Banzarov Buryat State University

24a Smolina St., Ulan-Ude 670000, Russia

E-mail: calidris03@gmail.com

Zhargal N. Dugarov

Cand. Sci. (Biol.), Senior Researcher,

Laboratory of Parasitology and Ecology of Hydrobionts

Institute of General and Experimental Biology SB RAS

6 Sakhyanovoy St., Ulan-Ude 670047, Russia

E-mail: zhar-dug@biol.bscnet.ru

An ecological and faunistic analysis of helminths in the Charadrii of Baikal Siberia was carried out. Majority of the material we collected on Lake Baikal. It has been established a systematic diversity of helminthofauna, which consists of 88 species from 4 classes and 17 families. In terms of species, cestodes predominate $(40.9 \%)$, trematodes account for just over one third $(34.1 \%)$, nematodes amount to one fifth $(23.7 \%)$, and there are very few acanthocephalans $(1.1 \%)$.

The ratio of different classes of parasites is noticeably different in subfamilies of charadriiformes. In plovers, sandpipers and Calidris cestodes prevailed, in lapwings, turnstones, pike smelts, Tringa and Haliplidae — trematodes. The greatest diversity of parasite species was found in little stints, wood sandpipers, and tereks.

A wide variety of hosts among Charadrii had cestodes Aploparaksis sachalinensis, Anomotaenia tringae, Aploparaksis crassirostris, Anomotaenia citrus, trematodes Plagiorchis nanus, Cyclocoelum mutabile, Leucochloridium actitis, Echinoparyphium politum, Plagiorchis vitellatus, nematodes Tetrameres dubia Porrocaecum semiteres. We have revealed many helminths specific for charadriiformes (Anomotaenia - A. citrus, A. globulus, A. tringae, etc., Pseudanomotaenia paramicrorhyncha, Trichocephaloides megalocephala, Aploparaksis sachalinensis, etc.).

Helminthofauna in different subfamilies of Charadriiformes has relatively small similarity, which is explained by differences in feeding habits, foraging behavior, and habitual area of different species.

Keywords: helminths; Charadriiformes; Lake Baikal; Baikal Siberia; bird parasites; helminthofauna. 